\title{
PERFORMANCE OF A RECIPROCAL SHAKER IN MECHANICAL DISPERSION OF SOIL SAMPLES FOR PARTICLE-SIZE ANALYSIS ${ }^{(1)}$
}

\author{
Thayse Aparecida Dourado(2), Laura Fernanda Simões da Silva ${ }^{(3)}$ \& Mara de Andrade \\ Marinho $^{(4)}$
}

\section{SUMMARY}

The dispersion of the samples in soil particle-size analysis is a fundamental step, which is commonly achieved with a combination of chemical agents and mechanical agitation. The purpose of this study was to evaluate the efficiency of a low-speed reciprocal shaker for the mechanical dispersion of soil samples of different textural classes. The particle size of 61 soil samples was analyzed in four replications, using the pipette method to determine the clay fraction and sieving to determine coarse, fine and total sand fractions. The silt content was obtained by difference. To evaluate the performance, the results of the reciprocal shaker (RSh) were compared with data of the same soil samples available in reports of the Proficiency testing for Soil Analysis Laboratories of the Agronomic Institute of Campinas (Prolab/IAC). The accuracy was analyzed based on the maximum and minimum values defining the confidence intervals for the particle-size fractions of each soil sample. Graphical indicators were also used for data comparison, based on dispersion and linear adjustment. The descriptive statistics indicated predominantly low variability in more than $90 \%$ of the results for sand, mediumtextured and clay samples, and for $68 \%$ of the results for heavy clay samples, indicating satisfactory repeatability of measurements with the RSh. Medium variability was frequently associated with silt, followed by the fine sand fraction. The sensitivity analyses indicated an accuracy of $100 \%$ for the three main separates

(1) Paper presented at the XXXII Brazilian Congress of Soil Science (Fortaleza, CE, 2-7/08/2009), during both oral and poster sections. Received in August 15, 2012 and approved in May 18, 2012.

${ }^{(2)}$ Undergraduate student at State University of Campinas, College of Agricultural Engineering - UNICAMP/FEAGRI. Financial support: Scientific Initiation Fellowship from SAE/UNICAMP. Av. Cândido Rondon, 501, Bairro Barão Geraldo. CEP 13083875 Campinas (SP). E-mail: thaysedourado@gmail.com

${ }^{(3)}$ Substitute Professor at Universidade Estadual Paulista - UNESP - Campus Rio Claro, Dept. of Petrology and Metallogeny, Institute of Geosciences and Exact Sciences. Avenida 24-A, 1515. CEP 13506-900. E-mail: laurafsimoes@yahoo.com

(4) Associate Professor at State University of Campinas, College of Agricultural Engineering - UNICAMP/ FEAGRI. E-mail: mara.marinho@feagri.unicamp.br 
(total sand, silt and clay), in all 52 samples of the textural classes heavy clay, clay and medium. For the nine sand soil samples, the average accuracy was $85.2 \%$; highest deviations were observed for the silt fraction. In relation to the linear adjustments, the correlation coefficients of 0.93 (silt) or $>0.93$ (total sand and clay), as well as the differences between the angular coefficients and the unit < 0.16, indicated a high correlation between the reference data (Prolab/IAC) and results obtained with the RSh. In conclusion, the mechanical dispersion by the reciprocal shaker of soil samples of different textural classes was satisfactory. The results allowed recommending the use of the equipment at low agitation for particle size- analysis. The advantages of this Brazilian apparatus are its low cost, the possibility to simultaneously analyze a great number of samples using ordinary, easily replaceable glass or plastic bottles.

Index terms: soil texture, pipette method, mechanical dispersion, accuracy analysis.

\section{RESUMO: AVALIAÇÃO DO DESEMPENHO DE MESA AGITADORA RECIPROCANTE NA DISPERSÃO DE AMOSTRAS DE SOLO PARA FINS DE ANÁLISE GRANULOMÉTRICA}

A dispersão da amostra de solo é uma etapa fundamental da análise granulométrica, sendo realizada mediante o uso de dispersantes químicos e agitação mecânica. $O$ objetivo deste trabalho foi avaliar a eficiência de mesa agitadora reciprocante de baixa rotação na dispersão mecânica de amostras de solos de diferentes classes texturais. Foram realizadas análises granulométricas em 61 amostras com quatro repetições, empregando o método da pipeta para determinação da fração argila e tamisagem para determinação das frações areia grossa, areia fina e areia total, sendo o silte determinado por diferença. Na avaliação de desempenho, os resultados obtidos com uso da mesa agitadora reciprocante (MAR) foram comparados com dados disponíveis para as mesmas amostras oriundos de relatórios do Ensaio de Proficiência IAC para Laboratórios de Análises de Solos - Prolab / IAC. Análises de acurácia foram realizadas com base nos valores dos intervalos de confiança definidos para cada fração granulométrica componente de cada amostra ensaiada. Indicadores gráficos também foram utilizados na comparação de dados, por meio de dispersão e ajuste linear. A estatistica descritiva indicou preponderância de baixa variabilidade em mais de $90 \%$ dos resultados obtidos para as amostras de texturas arenosa, média e argilosa e em $68 \%$ dos obtidos para as amostras de textura muito argilosa, indicando boa repetibilidade dos resultados obtidos com a MAR. Média variabilidade foi mais frequentemente associada à fração silte, seguida da fração areia fina. Os resultados das análises de sensibilidade indicam acurácia de 100 \% nas três frações granulométricas - areia total, silte e argila - para todas as amostras analisadas pertencentes às classes texturais muito argilosa, argilosa e média. Para as nove amostras de textura arenosa, a acurácia média foi de 85,2\%, e os maiores desvios ocorreram em relação à fração silte. Nas aproximações lineares, coeficientes de correlação igual (silte) ou superiores (areia total e argila) a 0,93, bem como diferenças menores do que 0,16 entre os coeficientes angulares das retas e o valor unitário, indicam alta correlação entre os resultados de referência (Prolab/IAC) e os obtidos nos ensaios com a $M A R$. Conclui-se pelo desempenho satisfatório da mesa agitadora reciprocante de baixa rotação para dispersão mecânica de amostras de solo de diferentes classes texturais para fins de análise granulométrica, permitindo recomendar o uso alternativo do equipamento quando se emprega agitação lenta. As vantagens do uso do equipamento nacional incluem o baixo custo, a possibilidade de análise simultânea de grande número de amostras e o uso de frascos comuns, de vidro ou de plástico, baratos e de fácil reposição.

Termos de indexação: granulometria, método da pipeta, dispersão mecânica, análise de acurácia. 


\section{INTRODUCTION}

Soil texture is based on different combinations of sand, silt, and clay separates that define the particlesize distribution of a soil sample (Gee \& Or, 2002). Particle-size distribution is a natural and permanent soil property and one of the most frequently used for soil characterization (Hillel, 1982). Because of the correlation between specific surface and particle size, the percentage distribution of the various sizes of individual particles within a soil is an important soil characteristic (Baver et al., 1972). The particle-size distribution of a soil is determined by particle-size analysis. Particle-size analysis is defined as a measurement of the size distribution of the individual (primary) particles in a soil sample, according to texture fractions in a given classification scheme (Baver et al., 1972; Gee \& Or, 2002). The analysis of particle sizes is a common and essential physical analysis of the soil, for which conventionally "fine earth" is used, or the soil fraction that can be sieved through $2 \mathrm{~mm}$ mesh. The size limits of the three main fractions of soil particles sand, silt and clay are given by diameter ranges, according to different scales. The sand fraction contains the largest particles, with diameters between 2.0 and $0.02 \mathrm{~mm}$ (ISSS) or 2.0 and $0.05 \mathrm{~mm}$ (USDA). Silt consists of medium-sized particles, with diameters from 0.02 to $0.002 \mathrm{~mm}$ (ISSS) or from 0.05 to $0.002 \mathrm{~mm}$ (USDA), and the clay fraction contains the smallest soil particles, with diameters below $0,002 \mathrm{~mm}$ or $0,2 \mu$ on both scales (Gee $\&$ Or, 2002).

Soil texture is widely recognized as being fundamental for soil identification and classification. More recently, particle-size distribution has been widely used as an independent variable in pedotransfer functions for the estimation of more complex soil physical properties (Tomasella et al., 2000, Silva et al., 2008). In the soil, organic matter, iron oxides and carbonates act as cementing agents, keeping the particles together and forming aggregates. The success of particle-size analysis depends firstly on the sample preparation to ensure a complete dispersion of all aggregates into their individual primary particles without breaking up the particles themselves and secondly, on the accurate fractionation of a sample into its different separates (Baver et al., 1972). Thus, the dispersion phase consists of the individualization of the soil primary particles in aqueous suspension, by using chemical agents and physical methods (Gee $\&$ Or, 2002). The chemical agents are used to eliminate the flocculating ions, such as $\mathrm{Al}$ and $\mathrm{Ca}$, to increase the repulsion between the primary particles, and to stabilize the individual particles in the suspension throughout the analysis (Gee \& Or, 2002; Ruiz, 2005). In Brazil, the Brazilian Agricultural Research Corporation - Embrapa (1997) recommends the chemical agents Na-hydroxide $(\mathrm{NaOH})$ or $\mathrm{Na}$ hexametaphosphate buffered with $\mathrm{Na}$-carbonate for normal soils, the use of hydrogen chloride $(\mathrm{HCl})$ at
$10 \%$ for calcareous soils, and Na-hexametaphosphate for saline soils. In São Paulo State, the Agronomic Institute of Campinas (IAC) recommends the use of a mixture of Na-hydroxide and Na-hexametaphosphate (Camargo et al., 1986). Sodium can adsorb high quantities of water and when the $\mathrm{Na}$ ion is adsorbed on the surface of soil particles it induces repulsion between them, which in turn facilitates the stabilization of the individual particles in suspension. In recent research, Neto et al. (2009) evaluated the effectiveness of different chemical agents for the dispersion of a Rhodic Hapludox irrigated with calcium-rich water. They concluded that the combination of hydrogen chloride $(\mathrm{HCl})$ with $\mathrm{Na}$ hydroxide $(\mathrm{NaOH})$ was the most efficient way of recovering the clay fraction. Classical physical methods of soil dispersion include fast or slow shaking or rolling of the soil suspension. In the past 20 years, electronic dispersion, primarily by the use of sonication, has become increasingly popular (Gee $\&$ Or, 2002). In Brazil, Embrapa (1997) recommends the use of electric stirrers at high speed $(10,000$ to $12,000 \mathrm{rpm}$ ) for a short stirring time, varying from $5 \mathrm{~min}$ (for sandy soils) to $15 \mathrm{~min}$ (for clayey soils). In São Paulo, Grohmann \& Raij (1977) demonstrated the superiority of slow shaking for a more efficient soil dispersion and clay determination for soil particle-size analysis performed in the IAC laboratories. Later, Camargo et al. (1986) recommended the use of low-speed stirrers (30 rpm), for example the Wiegner shaker, with longer stirring time, of about $16 \mathrm{~h}$. According to Gee \& Or (2002), not only a standardization of the treatments but also the testing of specific methodologies are needed, since the mechanical techniques can result in the fragmentation of the primary particles. The reciprocal shaker evaluated here belongs to the category of slowspeed shakers, for which there are no comparative performance studies based on the results obtained with methodologies and agitators commonly used in the laboratories. The advantages of this reciprocal shaker include its relatively low cost, the capacity to shake a large number (40) of samples simultaneously, and the possibility of using cheap and easy replaceable glass or plastic pots. Given the above, our objective was to evaluate the efficiency of a slow reciprocal shaker for the dispersion of soil samples of different textural classes for particle-size analysis.

\section{MATERIAL AND METHODS}

\section{Experimental location and characterization of the soil samples}

The experiment was conducted at the Soil Laboratory (Labsol) of the College of Agricultural Engineering, State University of Campinas, Campinas, SP. 
The tests were conducted with 61 soil samples of different textural classes. According to the textural groups defined by Embrapa (2006), the texture of nine of the soil samples was sandy (containing $<150 \mathrm{~g} \mathrm{~kg}^{-1}$ clay and $>700 \mathrm{~g} \mathrm{~kg}^{-1}$ sand), of 22 medium (with clay contents $<350 \mathrm{~g} \mathrm{~kg}^{-1}$ and $>150 \mathrm{~g} \mathrm{~kg}^{-1}$ ), of 20 samples clayey (with clay contents $>350 \mathrm{~g} \mathrm{~kg}^{-1}$ and $<600 \mathrm{~g}$ $\mathrm{kg}^{-1}$ ), and of the last 10 samples the texture was Heavy Clay (with clay contents $>600 \mathrm{~g} \mathrm{~kg}^{-1}$ ).

The samples were selected from a soil bank of the Labsol, due to its participation in the IAC Proficiency Testing for Soil Analyses Laboratories - Prolab/IAC. The choice of this soil sample bank was due to the availability of results of particle-size analyses performed by more than 80 laboratories participating in the program. The data were used as references in the performance evaluation of the reciprocating shaker. The statistical procedures used in the Prolab/ IAC define the average value and the acceptable range of results obtained for each particle-size fraction (coarse sand, fine sand, total sand, silt and clay) for each soil sample (Quaggio et al., 1994). The acceptable range depends on the coefficient of variation (CV) of the results for each particle-size fraction for each soil sample, according to the following criteria: a) for $\mathrm{CV}>40 \%$, the acceptable range is the average \pm 1.0 standard deviation $(s)$ calculated from the results obtained by all laboratories; b) for CV between 20 and $40 \%$, the acceptable range is the average $\pm 1.5 \mathrm{~s}$, and c) for $\mathrm{CV}<20 \%$, the acceptable range of results is the average $\pm 2.0 \mathrm{~s}$. These data sets of particle-size analyses determined independently and as a part of a soil analysis quality program, were considered appropriate to draw conclusions not only about the accuracy but also on the precision of the results obtained by mechanical dispersion with a reciprocal shaker (RSh).

\section{Analysis methods}

The particle-size analyses were carried out by the Pipette Method described by Day (1965) for clay determination, by sieving for separation of the sands and by the difference between the former to obtain silt, according to the procedures described by Embrapa (1997) and Camargo et al. (1986).

\section{a) Principles}

The pipette method is a direct sampling procedure based on the particle settling speed in an aqueous suspension according to Stokes' law (Equation 1). The basic assumptions to apply Stokes' law to soil suspensions are: a) the terminal velocity is reached as soon as settling begins; $b$ ) resistance to settling is entirely due to the viscosity of the fluid; c) particles are smooth and spherical; d) there is no interaction between individual particles in the suspension (Gee $\&$ Or, 2002). Since the soil particles are not smooth and spherical, $d$ must be regarded as equivalent rather than actual diameters. The methods of particle-size analysis based on the settling velocity determine the soil particles more precisely according to the settling time, as defined by equation 2 . For clay fraction determination, after the dispersion of the soil sample, the time and the distance of vertical displacement of the particles through the aqueous suspension are fixed, so that only the clay particles remain in suspension at that depth. At the time $t$, a small subsample is taken from the suspension at depth $h$, according to equation 2. After oven-drying and subtracting the dispersant weight (blank test), the clay mass of the soil sample is determined. To determine the sand fraction, the soil suspension is passed either through a set of two sieves, to separate the coarse from the fine sand fractions (ISSS), or through a set of five sieves, to separate the sand in very coarse, coarse, medium, fine and very fine (USDA). Then, the sand fractions are oven-dried and weighed for content determinations. After determining the sand and the clay fractions, the silt fraction is calculated by the difference (Camargo et al., 1986; Embrapa, 1997). The pipette method is often used as a standard method and the results of the particle-size analysis are expressed in $\mathrm{g} \mathrm{kg}^{-1}$ by the International System.

$$
\begin{aligned}
& \mathrm{v}=\frac{\mathrm{d}^{2} \mathrm{~g}\left(\rho_{\mathrm{S}}-\rho_{\mathrm{F}}\right)}{18 \eta} \\
& \mathrm{t}=\frac{9 \eta \mathrm{h}}{2\left(\rho_{\mathrm{S}}-\rho_{\mathrm{F}}\right) \mathrm{gr}^{2}}
\end{aligned}
$$

\section{b) Analytical procedure}

For soils with less than $5 \%$ of organic matter (OM) $\left(<50 \mathrm{~g} \mathrm{~kg}^{-1}\right), 10 \mathrm{~g}$ of the $<2 \mathrm{~mm}$ fraction of air-dried soil was weighed and transferred to a $500 \mathrm{~mL}$ glass pot with $50 \mathrm{~mL}$ of dispersant solution* (a mixture of $20 \mathrm{~g}$ of Na-hydroxide PA and $50 \mathrm{~g}$ of $\mathrm{Na}-$ hexametaphosphate in $5 \mathrm{~L}$ of distilled water, stirred with magnetic stirrer until the reagents were dissolved). After closing, the glass pot was placed on the low-speed reciprocal shaker (RSh) for mechanical stirring at $130 \mathrm{rpm}$ for $14-16 \mathrm{~h}$ (Figure 1).

The stirring velocity was determined based on preliminary tests at different speeds, which demonstrated that $130 \mathrm{rpm}$ was the ideal rotation speed to promote an effective movement of the suspension within the glass pot. For soils containing more than $5 \%$ of organic matter $\left(>50 \mathrm{~g} \mathrm{~kg}^{-1}\right)$, a pretreatment was required to eliminate $\mathrm{OM}$ as follows: fill $10 \mathrm{~g}$ of the $<2 \mathrm{~mm}$ fraction of air-dried fine earth into a $800 \mathrm{~mL}$ beaker, add $200 \mathrm{~mL}$ of Napyrophosphate $0.1 \mathrm{~mol} \mathrm{~L}^{-1}$ and $50 \mathrm{~mL}$ of hydrogen peroxide $\left(\mathrm{H}_{2} \mathrm{O}_{2} \sim 30 \%\right)$, and let it stand overnight. The next day, maintain at $40^{\circ} \mathrm{C}$ in water bath for 8 $\mathrm{h}$, and stir with a glass rod every $2 \mathrm{~h}$. To remove the excess of $\mathrm{H}_{2} \mathrm{O}_{2}$, raise the temperature to $80^{\circ} \mathrm{C}$, until almost dry. Wash the sample, centrifuge it twice with distilled water, and remove the supernatant. Air-dry the sample, grind and weigh the quantity required for the particle-size analysis. 
After the stirring period, the suspension was sieved through a $0.053 \mathrm{~mm}$ (270 mesh) into a $0.5 \mathrm{~L}$ sedimentation cylinder for sand separation. The material retained on the sieve (sand) was transferred to a $0.4 \mathrm{~L}$ beaker, and oven-dried at $105^{\circ} \mathrm{C}$. Then the dried sands were transferred to a set of two sieves: $0.21 \mathrm{~mm}$ (coarse sand) and $0.05 \mathrm{~mm}$ (fine sand), and shaken for $30 \mathrm{~min}$ on a sieve vibrator. The masses of the coarse sand and of the fine sand were weighed (precision $0.01 \mathrm{~g}$ ).

The volume of the suspended material was completed to $0.5 \mathrm{~L}$ and the test tube placed in a water bath. The suspension was stirred for $30 \mathrm{~s}$ with a glass rod with a plunger slightly smaller than the cylinder diameter attached to its lower end. The settling time was defined according to the suspension temperature.

After the sedimentation period required for clay recovery only, $10 \mathrm{~mL}$ of the suspension were pipetted from a depth of $5 \mathrm{~cm}$, transferred to a tared beaker (precision $0.0001 \mathrm{~g}$ ), and dried at $105{ }^{\circ} \mathrm{C}$ for $24 \mathrm{~h}$. After drying, the beaker was placed in a desiccator until reaching room temperature, then weighed (precision $0.0001 \mathrm{~g}$ ) and the weight of the clay + dispersing agents determined.

A blank test was performed to determine the weight of the dispersing agents by preparing a solution with the same concentration used in the analysis ( 50 $\mathrm{mL}$ of dispersing solution* in a sedimentation cylinder + water to complete $0.5 \mathrm{~L}$ ). A $10 \mathrm{~mL}$ aliquot of the solution was transferred to a beaker and oven-dried at $105^{\circ} \mathrm{C}$ for $24 \mathrm{~h}$. After drying, the beaker was placed in a desiccator until reaching room temperature; then it was weighed (precision $0.0001 \mathrm{~g}$ ) to determine the mass of the dispersing agents contained in the $10 \mathrm{~mL}$ aliquot. This value was subtracted from the weight of clay + dispersing agents to determine the clay content only.

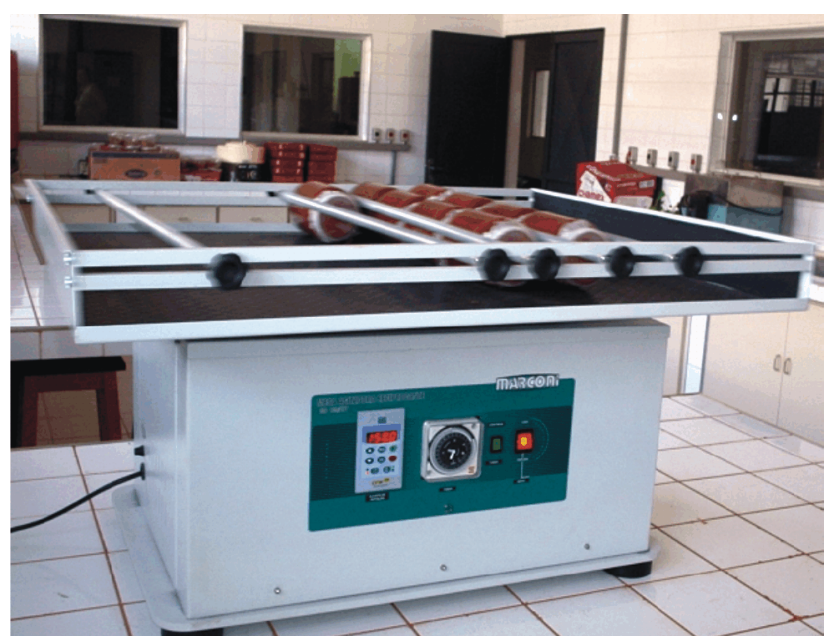

Figure 1. A view of the reciprocal shaker (RSh) as used for the mechanical dispersion of the soil samples using common glass pots.
The silt fraction was calculated by the difference between the sum of the sand and the clay fractions in relation to $1000 \mathrm{~g}$, since the results should be expressed in $\mathrm{g} \mathrm{kg}^{-1}$ (Camargo et al., 1986; Embrapa, 1997). For each soil sample, particle-size analysis was performed in four replications.

\section{c) Statistical analysis of the particle-size analysis results and performance evaluation of the reciprocal low speed shaker (RSh)}

The results were subjected to descriptive analysis to determine the following values: mean, standard deviation, and the maximum, minimum and coefficient of variation, using the SAS statistical program. The data variability, expressed by the coefficient of variation (CV\%), was evaluated according to the Warrick \& Nielsen (1980) criteria, by which coefficients below $12 \%$ indicate low variability; the coefficients varying between 12 and $60 \%$ medium variability; and the coefficients $>60 \%$ high variability.

For a performance analysis and to validate the results obtained with the RSh, the data accuracy was analyzed (Fletcher et al., 1986), based on confidence intervals (IC) as the criteria of acceptance, as defined by the particle-size data of the analysis performed with the same samples by the laboratories of the Prolab/ IAC program (Tables 1 and 2). Graphic indicators were also used to compare the results, using the ORIGINPRO $^{\mathrm{R}} 7.5$ software, which visualized data dispersion and the linear fit between the average content of a given particle-size fraction (sand, silt or clay) for each soil sample (reference data obtained from the Prolab/IAC program) and the value obtained using the RSh.

\section{RESULTS AND DISCUSSION}

The results of the descriptive analysis for coarse sand, fine sand, total sand, clay and silt fractions for nine sandy soil samples (containing $<150 \mathrm{~g} \mathrm{~kg}^{-1}$ clay and $>700 \mathrm{~g} \mathrm{~kg}^{-1}$ sand) are shown in Table 3 . For all sandy samples (9), the coefficients of variation (CV) of the results for fine sand, total sand and clay were lower than $12 \%$, indicating low variability. The variability in the results for coarse sand was also low, except for sample 2, for which the CV of $13.95 \%$ indicated medium variability, according to the criteria of Warrick \& Nielsen (1980). For silt, medium variability was observed for three samples $(2,4$ and 6); however, for the remaining six samples, variability was also low. In general, low variability was characterized for $91 \%$ of the results obtained for the sandy soil samples.

The results shown in table 4 were obtained from 21 medium-textured soil samples. For almost $92 \%$ of the data, including coarse sand, total sand and clay fractions of all tested samples, variability was low 
$(\mathrm{CV}<12 \%)$; medium variability $(12 \%<\mathrm{CV}<60 \%)$ was only observed for fine sand (samples 22,23 and 27) and silt (samples 12, 16, 17, 27 and 30).

For the set of 20 clayey soil samples, variability was low in $93 \%$ of the results; for 15 samples, variability was low for all fractions: coarse sand, fine sand, total sand, silt, and clay (Table 5). Medium variability was only inferred for fine sand (samples 37, 39 and 45), coarse sand (sample 43) and silt (samples 37, 41 and 45).

Finally, low variability was observed in $68 \%$ of the results obtained for 10 Heavy Clay soil samples,

Table 1. Confidence intervals for coarse, fine and total sand, and silt and Clay contents for nine sandy and 22 medium textured soil samples

\begin{tabular}{|c|c|c|c|c|c|}
\hline \multirow{2}{*}{ Sample } & \multicolumn{3}{|c|}{ Sand } & \multirow{2}{*}{ Clay } & \multirow{2}{*}{ Silt } \\
\hline & Coarse & Fine & Total & & \\
\hline & \multicolumn{5}{|c|}{$-\mathrm{g} \mathrm{kg}^{-1}$} \\
\hline & \multicolumn{5}{|c|}{ Sandy soil samples } \\
\hline 1 & 188 to 458 & 297 to 568 & 710 to 807 & 83 to 177 & 68 to 152 \\
\hline 2 & 289 to 561 & 271 to 573 & 781 to 910 & 51 to 110 & 44 to 86 \\
\hline 3 & 232 to 501 & 337 to 606 & 787 to 885 & 64 to 123 & 38 to 88 \\
\hline 4 & 324 to 668 & 294 to 555 & 897 to 949 & 35 to 77 & 11 to 31 \\
\hline 5 & 323 to 553 & 282 to 540 & 784 to 929 & 44 to 82 & 41 to 100 \\
\hline 6 & 273 to 595 & 308 to 644 & 875 to 955 & 38 to 76 & 15 to 35 \\
\hline 7 & 259 to 496 & 307 to 635 & 806 to 894 & 56 to 108 & 44 to 89 \\
\hline 8 & 251 to 525 & 272 to 599 & 795 to 875 & 66 to 131 & 39 to 87 \\
\hline \multirow[t]{2}{*}{9} & 241 to 527 & 295 to 596 & 802 to 867 & 63 to 130 & 46 to 92 \\
\hline & \multicolumn{5}{|c|}{ Medium textured soil samples } \\
\hline 10 & 352 to 497 & 141 to 283 & 606 to 665 & 235 to 359 & 47 to 95 \\
\hline 11 & 385 to 452 & 84 to 151 & 474 to 600 & 235 to 391 & 101 to 196 \\
\hline 12 & 300 to 457 & 140 to 291 & 543 to 634 & 268 to 388 & 59 to 116 \\
\hline 13 & 391 to 466 & 88 to 135 & 501 to 578 & 254 to 369 & 99 to 183 \\
\hline 14 & 387 to 449 & 94 to 144 & 501 to 571 & 267 to 369 & 98 to 186 \\
\hline 15 & 242 to 413 & 166 to 323 & 528 to 612 & 272 to 402 & 55 to 128 \\
\hline 16 & 409 to 534 & 69 to 116 & 530 to 614 & 244 to 373 & 83 to 167 \\
\hline 17 & 285 to 461 & 158 to 288 & 559 to 625 & 286 to 395 & 31 to 106 \\
\hline 18 & 267 to 394 & 181 to 304 & 545 to 602 & 303 to 375 & 58 to 118 \\
\hline 19 & 299 to 446 & 165 to 260 & 564 to 624 & 297 to 386 & 43 to 95 \\
\hline 20 & 305 to 419 & 182 to 269 & 564 to 618 & 299 to 374 & 51 to 97 \\
\hline 21 & 276 to 386 & 193 to 291 & 553 to 594 & 301 to 371 & 66 to 117 \\
\hline 22 & 287 to 418 & 157 to 275 & 540 to 599 & 286 to 382 & 62 to 133 \\
\hline 23 & 412 to 559 & 118 to 223 & 620 to 707 & 173 to 268 & 79 to 149 \\
\hline 24 & 356 to 464 & 69 to 143 & 476 to 564 & 279 to 392 & 107 to 180 \\
\hline 25 & 255 to 380 & 197 to 334 & 538 to 644 & 250 to 371 & 63 to 142 \\
\hline 26 & 373 to 467 & 82 to 124 & 491 to 558 & 266 to 397 & 98 to 179 \\
\hline 27 & 385 to 456 & 83 to 128 & 477 to 567 & 285 to 380 & 103 to 183 \\
\hline 28 & 298 to 431 & 162 to 298 & 548 to 634 & 241 to 349 & 80 to 160 \\
\hline 29 & 321 to 425 & 173 to 263 & 553 to 628 & 257 to 335 & 71 to 156 \\
\hline 30 & 507 to 615 & 62 to 138 & 583 to 734 & 197 to 283 & 60 to 129 \\
\hline 31 & 296 to 431 & 196 to 327 & 581 to 680 & 225 to 306 & 64 to 146 \\
\hline
\end{tabular}

Source: Values extracted from the Prolab/IAC reports. 
including the clay fraction (all samples), coarse sand (samples 54, 55, 56, 57), fine sand (samples 52, 54, $55,56,57,58,59,61$ ), total sand (samples $52,54,55$, $56,57,58)$ and silt (samples 53, 54, 56, 57, 58). Medium variability was inferred for coarse sand (samples 52, 53, 58, 59, 60, 61), fine sand (sample
53), total sand (samples 53, 59,60,61), and silt (samples 52, 55, 59, 60, 61).

The prevalence of low variability for various data sets indicates a good repeatability of the results of the analysis using the low speed reciprocal shaker (RSh). Medium variability was characterized

Table 2. Confidence intervals for coarse sand, fine sand, total sand, silt and clay contents for 20 Clayey soil samples and for 10 Heavy Clay soil samples

\begin{tabular}{|c|c|c|c|c|c|}
\hline \multirow{2}{*}{ Sample } & \multicolumn{3}{|c|}{ Sand } & \multirow{2}{*}{ Clay } & \multirow{2}{*}{ Silt } \\
\hline & Coarse & Fine & Total & & \\
\hline & \multicolumn{5}{|c|}{$\mathrm{g} \mathrm{kg}^{-1}$} \\
\hline & \multicolumn{5}{|c|}{ Clayey soil samples } \\
\hline 32 & 183 to 264 & 105 to 159 & 307 to 417 & 401 to 568 & 94 to 203 \\
\hline 33 & 271 to 361 & 79 to 141 & 379 to 479 & 322 to 466 & 109 to 242 \\
\hline 34 & 122 to 180 & 92 to 148 & 216 to 329 & 457 to 622 & 116 to 261 \\
\hline 35 & 118 to 188 & 89 to 150 & 215 to 333 & 459 to 603 & 133 to 248 \\
\hline 36 & 196 to 268 & 104 to 163 & 327 to 403 & 404 to 570 & 102 to 195 \\
\hline 37 & 215 to 336 & 71 to 147 & 308 to 483 & 310 to 509 & 126 to 248 \\
\hline 38 & 138 to 171 & 99 to 143 & 229 to 322 & 472 to 638 & 101 to 215 \\
\hline 39 & 188 to 264 & 103 to 173 & 325 to 400 & 434 to 542 & 95 to 200 \\
\hline 40 & 126 to 178 & 96 to 143 & 242 to 304 & 480 to 604 & 116 to 251 \\
\hline 41 & 239 to 341 & 145 to 235 & 454 to 506 & 365 to 478 & 62 to 128 \\
\hline 42 & 30 to 62 & 69 to 134 & 103 to 194 & 406 to 603 & 240 to 456 \\
\hline 43 & 27 to 60 & 52 to 103 & 76 to 160 & 421 to 623 & 251 to 448 \\
\hline 44 & 252 to 347 & 147 to 223 & 461 to 506 & 373 to 460 & 71 to 131 \\
\hline 45 & 24 to 53 & 46 to 100 & 76 to 148 & 436 to 694 & 194 to 423 \\
\hline 46 & 237 to 340 & 154 to 227 & 455 to 507 & 380 to 452 & 72 to 135 \\
\hline 47 & 227 to 314 & 151 to 225 & 431 to 485 & 391 to 492 & 63 to 136 \\
\hline 48 & 242 to 322 & 92 to 168 & 374 to 451 & 353 to 518 & 100 to 205 \\
\hline 49 & 231 to 340 & 74 to 134 & 361 to 426 & 411 to 502 & 105 to 200 \\
\hline 50 & 124 to 287 & 71 to 136 & 205 to 408 & 332 to 574 & 176 to 308 \\
\hline \multirow[t]{2}{*}{51} & 85 to 128 & 145 to 226 & 250 to 338 & 482 to 610 & 101 to 219 \\
\hline & \multicolumn{5}{|c|}{ Heavy Clay Soil Samples } \\
\hline 52 & 40 to 77 & 60 to 110 & 100 to 214 & 526 to 737 & 122 to 283 \\
\hline 53 & 11 to 32 & 7 to 27 & 16 to 75 & 578 to 735 & 220 to 381 \\
\hline 54 & 40 to 76 & 65 to 108 & 113 to 181 & 520 to 741 & 142 to 280 \\
\hline 55 & 40 to 77 & 69 to 102 & 106 to 186 & 560 to 720 & 133 to 283 \\
\hline 56 & 48 to 83 & 97 to 139 & 147 to 214 & 508 to 698 & 136 to 282 \\
\hline 57 & 43 to 89 & 96 to 142 & 153 to 215 & 541 to 683 & 124 to 279 \\
\hline 58 & 42 to 85 & 99 to 139 & 147 to 218 & 542 to 677 & 135 to 272 \\
\hline 59 & 44 to 91 & 103 to 142 & 156 to 226 & 543 to 677 & 125 to 282 \\
\hline 60 & 52 to 86 & 101 to 146 & 159 to 229 & 554 to 677 & 131 to 253 \\
\hline 61 & 49 to 88 & 104 to 146 & 167 to 223 & 559 to 673 & 128 to 241 \\
\hline
\end{tabular}

Source: Values extracted from the Prolab/IAC reports. 
Table 3. Descriptive statistics of the results from particle-size analyses of nine Sandy soil samples $(\mathrm{n}=4$ replications)

\begin{tabular}{|c|c|c|c|c|c|c|}
\hline Sample & Textural fraction & Mean & Standard deviation & Maximum & Minimum & $\mathbf{C V}$ \\
\hline & & & $\mathrm{g} \mathrm{k}_{\xi}$ & & & $\%$ \\
\hline \multirow[t]{5}{*}{1} & Coarse Sand & 269 & 9.12 & 283 & 242 & 7.12 \\
\hline & Fine Sand & 475 & 18.92 & 500 & 458 & 3.98 \\
\hline & Total Sand & 744 & 3.00 & 746 & 740 & 0.4 \\
\hline & Clay & 117 & 3.37 & 122 & 115 & 2.88 \\
\hline & Silt & 140 & 2.87 & 144 & 138 & 2.06 \\
\hline \multirow[t]{5}{*}{2} & Coarse Sand & 315 & 43.96 & 352 & 256 & 13.95 \\
\hline & Fine Sand & 507 & 29.85 & 548 & 485 & 5.81 \\
\hline & Total Sand & 822 & 14.32 & 837 & 804 & 1.74 \\
\hline & Clay & 66 & 2.63 & 68 & 62 & 3.99 \\
\hline & Silt & 112 & 14.08 & 130 & 96 & 12.63 \\
\hline \multirow[t]{5}{*}{3} & Coarse Sand & 303 & 23.64 & 336 & 284 & 7.80 \\
\hline & Fine Sand & 532 & 18.23 & 546 & 505 & 3.43 \\
\hline & Total Sand & 835 & 7.59 & 841 & 824 & 0.91 \\
\hline & Clay & 76 & 2.75 & 79 & 73 & 3.61 \\
\hline & Silt & 89 & 7.54 & 98 & 82 & 8.45 \\
\hline \multirow[t]{5}{*}{4} & Coarse Sand & 419 & 19.41 & 447 & 402 & 4.63 \\
\hline & Fine Sand & 510 & 17.26 & 524 & 485 & 3.38 \\
\hline & Total Sand & 929 & 2.50 & 932 & 926 & 0.27 \\
\hline & Clay & 43 & 3.37 & 47 & 39 & 7.83 \\
\hline & Silt & 28 & 4.92 & 32 & 23 & 17.75 \\
\hline \multirow[t]{5}{*}{5} & Coarse Sand & 372 & 30.72 & 402 & 341 & 8.25 \\
\hline & Fine Sand & 470 & 25.72 & 494 & 442 & 5.47 \\
\hline & Total Sand & 842 & 6.24 & 850 & 835 & 0.74 \\
\hline & Clay & 45 & 1.16 & 46 & 44 & 2.57 \\
\hline & Silt & 113 & 5.32 & 119 & 106 & 4.73 \\
\hline \multirow[t]{5}{*}{6} & Coarse Sand & 355 & 23.42 & 388 & 336 & 6.60 \\
\hline & Fine Sand & 570 & 18.08 & 585 & 544 & 3.18 \\
\hline & Total Sand & 925 & 5.45 & 932 & 920 & 0.59 \\
\hline & Clay & 44 & 3.32 & 48 & 40 & 7.45 \\
\hline & Silt & 31 & 5.48 & 35 & 23 & 17.67 \\
\hline \multirow[t]{5}{*}{7} & Coarse Sand & 330 & 20.63 & 357 & 307 & 6.26 \\
\hline & Fine Sand & 508 & 29.87 & 545 & 472 & 5.87 \\
\hline & Total Sand & 838 & 9.90 & 852 & 829 & 1.18 \\
\hline & Clay & 69 & 5.60 & 74 & 62 & 8.11 \\
\hline & Silt & 93 & 4.97 & 97 & 86 & 5.34 \\
\hline \multirow[t]{5}{*}{8} & Coarse Sand & 326 & 20.05 & 353 & 308 & 6.15 \\
\hline & Fine Sand & 499 & 20.04 & 514 & 471 & 4.01 \\
\hline & Total Sand & 825 & 3.40 & 828 & 821 & 0.41 \\
\hline & Clay & 84 & 2.06 & 87 & 82 & 0.45 \\
\hline & Silt & 91 & 1.92 & 92 & 88 & 2.12 \\
\hline \multirow[t]{5}{*}{9} & Coarse Sand & 320 & 30.93 & 349 & 293 & 9.66 \\
\hline & Fine Sand & 508 & 28.04 & 533 & 482 & 5.53 \\
\hline & Total Sand & 828 & 3.11 & 831 & 824 & 0.38 \\
\hline & Clay & 84 & 3.50 & 88 & 80 & 4.15 \\
\hline & Silt & 88 & 1.71 & 90 & 86 & 1.94 \\
\hline
\end{tabular}


Table 4. Descriptive statistics of the results from particle-size analyses of 21 Medium textured soil samples $(n=4$ replications $)$

\begin{tabular}{|c|c|c|c|c|c|c|}
\hline Sample & Textural fraction & Mean & Standard deviation & Maximum & Minimum & CV \\
\hline & & & - $\mathrm{g} \mathrm{kg}$ & & & $\%$ \\
\hline \multirow[t]{5}{*}{10} & Coarse Sand & 379 & 38.06 & 416 & 340 & 10.05 \\
\hline & Fine Sand & 264 & 28.47 & 288 & 235 & 10.80 \\
\hline & Total Sand & 642 & 10.48 & 651 & 628 & 1.63 \\
\hline & Clay & 275 & 13.40 & 287 & 256 & 4.86 \\
\hline & Silt & 83 & 8.42 & 93 & 73 & 10.17 \\
\hline \multirow[t]{5}{*}{11} & Coarse Sand & 432 & 13.24 & 446 & 415 & 3.06 \\
\hline & Fine Sand & 113 & 9.63 & 123 & 104 & 8.51 \\
\hline & Total Sand & 545 & 6.60 & 550 & 536 & 1.21 \\
\hline & Clay & 328 & 9.39 & 339 & 320 & 2.86 \\
\hline & Silt & 127 & 10.86 & 135 & 111 & 8.55 \\
\hline \multirow[t]{5}{*}{12} & Coarse Sand & 334 & 13.52 & 346 & 317 & 4.05 \\
\hline & Fine Sand & 259 & 10.34 & 272 & 249 & 4.00 \\
\hline & Total Sand & 592 & 4.24 & 598 & 589 & 0.71 \\
\hline & Clay & 331 & 22.80 & 365 & 316 & 6.88 \\
\hline & Silt & 77 & 21.26 & 95 & 46 & 27.70 \\
\hline \multirow[t]{5}{*}{13} & Coarse Sand & 424 & 2.38 & 427 & 422 & 0.56 \\
\hline & Fine Sand & 121 & 2.62 & 125 & 119 & 2.16 \\
\hline & Total Sand & 545 & 2.06 & 547 & 543 & 0.37 \\
\hline & Clay & 325 & 9.35 & 334 & 312 & 2.87 \\
\hline & Silt & 130 & 7.74 & 141 & 123 & 5.95 \\
\hline \multirow[t]{5}{*}{14} & Coarse Sand & 420 & 25.10 & 447 & 396 & 5.98 \\
\hline & Fine Sand & 120 & 12.44 & 132 & 109 & 10.35 \\
\hline & Total Sand & 540 & 13.54 & 557 & 526 & 2.50 \\
\hline & Clay & 328 & 11.81 & 342 & 316 & 3.60 \\
\hline & Silt & 133 & 10.21 & 147 & 124 & 7.70 \\
\hline \multirow[t]{5}{*}{15} & Coarse Sand & 307 & 15.77 & 324 & 287 & 5.13 \\
\hline & Fine Sand & 266 & 10.07 & 277 & 253 & 3.77 \\
\hline & Total Sand & 574 & 7.25 & 581 & 564 & 1.26 \\
\hline & Clay & 325 & 8.22 & 336 & 316 & 2.52 \\
\hline & Silt & 101 & 6.50 & 110 & 95 & 6.45 \\
\hline \multirow[t]{5}{*}{16} & Coarse Sand & 476 & 51.59 & 521 & 406 & 10.83 \\
\hline & Fine Sand & 84 & 9.60 & 98 & 76 & 11.40 \\
\hline & Total Sand & 561 & 49.18 & 597 & 489 & 8.77 \\
\hline & Clay & 290 & 8.00 & 302 & 286 & 2.75 \\
\hline & Silt & 149 & 50.62 & 225 & 117 & 33.86 \\
\hline \multirow[t]{5}{*}{17} & Coarse Sand & 336 & 13.96 & 347 & 316 & 4.14 \\
\hline & Fine Sand & 247 & 7.78 & 258 & 241 & 3.15 \\
\hline & Total Sand & 584 & 6.45 & 588 & 574 & 1.10 \\
\hline & Clay & 332 & 7.27 & 337 & 321 & 2.19 \\
\hline & Silt & 85 & 13.67 & 105 & 76 & 16.13 \\
\hline \multirow[t]{5}{*}{18} & Coarse Sand & 283 & 6.97 & 293 & 277 & 2.46 \\
\hline & Fine Sand & 285 & 6.48 & 293 & 280 & 2.26 \\
\hline & Total Sand & 569 & 5.03 & 574 & 562 & 0.88 \\
\hline & Clay & 332 & 6.83 & 341 & 325 & 2.05 \\
\hline & Silt & 99 & 4.00 & 105 & 97 & 4.04 \\
\hline \multirow[t]{5}{*}{19} & Coarse Sand & 347 & 34.59 & 380 & 304 & 9.97 \\
\hline & Fine Sand & 238 & 21.30 & 263 & 217 & 8.95 \\
\hline & Total Sand & 585 & 13.42 & 597 & 567 & 2.29 \\
\hline & Clay & 331 & 7.22 & 338 & 325 & 2.18 \\
\hline & Silt & 84 & 7.52 & 95 & 78 & 8.96 \\
\hline
\end{tabular}


Table 4. Cont.

\begin{tabular}{|c|c|c|c|c|c|c|}
\hline Sample & Textural fraction & Mean & Standard deviation & Maximum & Minimum & $\mathbf{C V}$ \\
\hline & & & $\mathrm{g} \mathrm{kg}$ & & & $\%$ \\
\hline \multirow[t]{5}{*}{20} & Coarse Sand & 336 & 13.24 & 346 & 317 & 3.94 \\
\hline & Fine Sand & 245 & 10.47 & 255 & 231 & 4.28 \\
\hline & Total Sand & 581 & 7.23 & 587 & 572 & 1.24 \\
\hline & Clay & 336 & 13.42 & 354 & 324 & 3.99 \\
\hline & Silt & 83 & 6.50 & 89 & 74 & 7.80 \\
\hline \multirow[t]{5}{*}{21} & Coarse Sand & 340 & 16.87 & 363 & 326 & 4.96 \\
\hline & Fine Sand & 240 & 15.34 & 257 & 220 & 6.39 \\
\hline & Total Sand & 580 & 4.85 & 583 & 573 & 0.83 \\
\hline & Clay & 327 & 10.23 & 341 & 318 & 3.12 \\
\hline & Silt & 93 & 5.85 & 99 & 86 & 6.30 \\
\hline \multirow[t]{5}{*}{22} & Coarse Sand & 329 & 31.03 & 363 & 295 & 9.43 \\
\hline & Fine Sand & 248 & 36.76 & 289 & 210 & 14.82 \\
\hline & Total Sand & 577 & 6.05 & 584 & 571 & 1.04 \\
\hline & Clay & 326 & 10.47 & 336 & 312 & 3.21 \\
\hline & Silt & 98 & 4.65 & 104 & 93 & 4.77 \\
\hline \multirow[t]{5}{*}{23} & Coarse Sand & 489 & 26.21 & 508 & 450 & 5.36 \\
\hline & Fine Sand & 180 & 22.36 & 213 & 167 & 12.46 \\
\hline & Total Sand & 668 & 6.68 & 676 & 662 & 1.00 \\
\hline & Clay & 217 & 5.12 & 224 & 212 & 2.36 \\
\hline & Silt & 115 & 3.94 & 121 & 112 & 3.42 \\
\hline \multirow[t]{5}{*}{24} & Coarse Sand & 411 & 4.03 & 416 & 407 & 0.98 \\
\hline & Fine Sand & 107 & 4.57 & 114 & 104 & 4.26 \\
\hline & Total Sand & 519 & 4.04 & 522 & 513 & 0.77 \\
\hline & Clay & 346 & 3.77 & 349 & 342 & 1.09 \\
\hline & Silt & 136 & 5.88 & 144 & 130 & 4.32 \\
\hline \multirow[t]{5}{*}{25} & Coarse Sand & 292 & 23.36 & 305 & 257 & 8.00 \\
\hline & Fine Sand & 301 & 16.17 & 325 & 292 & 5.37 \\
\hline & Total Sand & 593 & 7.22 & 597 & 582 & 1.21 \\
\hline & Clay & 299 & 7.43 & 309 & 292 & 2.48 \\
\hline & Silt & 109 & 3.10 & 111 & 104 & 2.86 \\
\hline \multirow[t]{5}{*}{26} & Coarse Sand & 415 & 23.18 & 449 & 400 & 5.59 \\
\hline & Fine Sand & 111 & 13.22 & 120 & 91 & 11.97 \\
\hline & Total Sand & 525 & 11.16 & 540 & 516 & 2.12 \\
\hline & Clay & 337 & 12.01 & 349 & 325 & 3.56 \\
\hline & Silt & 138 & 4.71 & 145 & 135 & 3.41 \\
\hline \multirow[t]{5}{*}{27} & Coarse Sand & 428 & 10.62 & 436 & 413 & 2.48 \\
\hline & Fine Sand & 75 & 44.37 & 106 & 10 & 58.58 \\
\hline & Total Sand & 504 & 44.76 & 534 & 437 & 8.89 \\
\hline & Clay & 338 & 6.84 & 348 & 334 & 2.02 \\
\hline & Silt & 159 & 47.57 & 229 & 128 & 29.96 \\
\hline \multirow[t]{5}{*}{28} & Coarse Sand & 345 & 9.69 & 359 & 338 & 2.81 \\
\hline & Fine Sand & 262 & 11.72 & 273 & 245 & 4.47 \\
\hline & Total Sand & 607 & 2.62 & 611 & 605 & 0.43 \\
\hline & Clay & 297 & 3.41 & 301 & 293 & 1.15 \\
\hline & Silt & 96 & 2.06 & 99 & 94 & 2.14 \\
\hline \multirow[t]{5}{*}{29} & Coarse Sand & 353 & 14.27 & 368 & 336 & 4.04 \\
\hline & Fine Sand & 250 & 13.88 & 265 & 234 & 5.56 \\
\hline & Total Sand & 602 & 0.95 & 603 & 601 & 0.15 \\
\hline & Clay & 297 & 6.68 & 304 & 288 & 2.25 \\
\hline & Silt & 101 & 7.50 & 111 & 93 & 7.44 \\
\hline \multirow[t]{5}{*}{30} & Coarse Sand & 586 & 10.87 & 599 & 575 & 1.85 \\
\hline & Fine Sand & 83 & 4.69 & 88 & 79 & 5.65 \\
\hline & Total Sand & 669 & 6.65 & 678 & 663 & 0.99 \\
\hline & Clay & 229 & 22.54 & 262 & 213 & 9.85 \\
\hline & Silt & 103 & 18.44 & 114 & 75 & 17.99 \\
\hline
\end{tabular}


Table 5. Descriptive statistics of the results from particle-size analysis of 20 Clay soil samples (n = 4 replications)

\begin{tabular}{|c|c|c|c|c|c|c|}
\hline Sample & Textural fraction & Mean & Standard deviation & Maximum & Minimum & $\mathbf{C V}$ \\
\hline & & & g kq & & & $\%$ \\
\hline \multirow[t]{5}{*}{32} & Coarse Sand & 236 & 5.16 & 242 & 230 & 2.18 \\
\hline & Fine Sand & 133 & 4.65 & 138 & 127 & 3.51 \\
\hline & Total Sand & 369 & 0.57 & 369 & 368 & 0.15 \\
\hline & Clay & 493 & 7.14 & 498 & 482 & 1.45 \\
\hline & Silt & 139 & 6.78 & 149 & 134 & 4.87 \\
\hline \multirow[t]{5}{*}{33} & Coarse Sand & 296 & 11.23 & 309 & 283 & 3.79 \\
\hline & Fine Sand & 127 & 8.96 & 135 & 115 & 7.08 \\
\hline & Total Sand & 422 & 2.87 & 424 & 418 & 0.68 \\
\hline & Clay & 442 & 9.53 & 450 & 428 & 2.15 \\
\hline & Silt & 136 & 12.35 & 154 & 126 & 9.08 \\
\hline \multirow[t]{5}{*}{34} & Coarse Sand & 161 & 7.67 & 167 & 150 & 4.76 \\
\hline & Fine Sand & 115 & 8.50 & 128 & 111 & 7.37 \\
\hline & Total Sand & 277 & 1.91 & 278 & 274 & 0.69 \\
\hline & Clay & 566 & 9.67 & 574 & 554 & 1.70 \\
\hline & Silt & 157 & 8.13 & 168 & 150 & 5.17 \\
\hline \multirow[t]{5}{*}{35} & Coarse Sand & 156 & 9.57 & 168 & 148 & 6.15 \\
\hline & Fine Sand & 118 & 4.35 & 120 & 111 & 3.70 \\
\hline & Total Sand & 273 & 12.67 & 288 & 259 & 4.64 \\
\hline & Clay & 572 & 3.59 & 577 & 569 & 0.62 \\
\hline & Silt & 155 & 13.93 & 172 & 142 & 9.00 \\
\hline \multirow[t]{5}{*}{36} & Coarse Sand & 237 & 9.39 & 248 & 225 & 3.96 \\
\hline & Fine Sand & 132 & 5.56 & 138 & 125 & 4.22 \\
\hline & Total Sand & 369 & 7.18 & 375 & 359 & 1.95 \\
\hline & Clay & 499 & 12.50 & 508 & 481 & 2.50 \\
\hline & Silt & 133 & 7.88 & 144 & 126 & 5.92 \\
\hline \multirow[t]{5}{*}{37} & Coarse Sand & 253 & 27.42 & 291 & 226 & 10.86 \\
\hline & Fine Sand & 105 & 23.6 & 140 & 91 & 22.44 \\
\hline & Total Sand & 358 & 24.93 & 389 & 337 & 6.97 \\
\hline & Clay & 470 & 35.77 & 507 & 425 & 7.61 \\
\hline & Silt & 173 & 26.97 & 204 & 146 & 15.61 \\
\hline \multirow[t]{5}{*}{38} & Coarse Sand & 151 & 7.87 & 158 & 140 & 5.21 \\
\hline & Fine Sand & 116 & 9.60 & 125 & 104 & 8.24 \\
\hline & Total Sand & 267 & 5.19 & 274 & 262 & 1.94 \\
\hline & Clay & 578 & 8.13 & 585 & 567 & 1.40 \\
\hline & Silt & 155 & 9.27 & 168 & 147 & 5.98 \\
\hline \multirow[t]{5}{*}{39} & Coarse Sand & 244 & 9.83 & 256 & 233 & 4.02 \\
\hline & Fine Sand & 120 & 18.51 & 130 & 92 & 15.46 \\
\hline & Total Sand & 364 & 12.36 & 377 & 348 & 3.39 \\
\hline & Clay & 506 & 7.54 & 512 & 498 & 1.49 \\
\hline & Silt & 131 & 15.59 & 154 & 120 & 11.90 \\
\hline \multirow[t]{5}{*}{40} & Coarse Sand & 163 & 4.78 & 167 & 156 & 2.94 \\
\hline & Fine Sand & 113 & 2.58 & 116 & 110 & 2.28 \\
\hline & Total Sand & 276 & 4.11 & 281 & 272 & 1.49 \\
\hline & Clay & 565 & 12.60 & 575 & 547 & 2.23 \\
\hline & Silt & 159 & 14.94 & 181 & 148 & 9.39 \\
\hline \multirow[t]{5}{*}{41} & Coarse Sand & 299 & 20.96 & 324 & 276 & 7.01 \\
\hline & Fine Sand & 190 & 10.32 & 202 & 178 & 5.43 \\
\hline & Total Sand & 489 & 10.67 & 502 & 478 & 2.18 \\
\hline & Clay & 410 & 9.03 & 418 & 398 & 2.20 \\
\hline & Silt & 101 & 16.50 & 124 & 89 & 16.37 \\
\hline
\end{tabular}


Table 5. Cont.

\begin{tabular}{|c|c|c|c|c|c|c|}
\hline Sample & Textural fraction & Mean & Standard deviation & Maximum & Minimum & CV \\
\hline & & & $\mathrm{g} \mathrm{k}$ & & & $\%$ \\
\hline \multirow[t]{5}{*}{42} & Coarse Sand & 40 & 4.35 & 42 & 33 & 11.03 \\
\hline & Fine Sand & 93 & 3.26 & 97 & 89 & 3.51 \\
\hline & Total Sand & 132 & 5.68 & 139 & 126 & 4.29 \\
\hline & Clay & 544 & 5.88 & 550 & 536 & 1.08 \\
\hline & Silt & 323 & 10.96 & 338 & 315 & 3.39 \\
\hline \multirow[t]{5}{*}{43} & Coarse Sand & 37 & 5.56 & 42 & 29 & 15.25 \\
\hline & Fine Sand & 76 & 5.56 & 83 & 70 & 7.37 \\
\hline & Total Sand & 112 & 4.89 & 118 & 106 & 4.37 \\
\hline & Clay & 554 & 9.97 & 563 & 542 & 1.08 \\
\hline & Silt & 334 & 8.22 & 346 & 327 & 2.45 \\
\hline \multirow[t]{5}{*}{44} & Coarse Sand & 265 & 20.00 & 291 & 243 & 7.54 \\
\hline & Fine Sand & 207 & 14.75 & 221 & 187 & 7.14 \\
\hline & Total Sand & 472 & 5.80 & 478 & 464 & 1.23 \\
\hline & Clay & 423 & 14.66 & 438 & 407 & 3.46 \\
\hline & Silt & 106 & 9.32 & 115 & 97 & 8.84 \\
\hline \multirow[t]{5}{*}{45} & Coarse Sand & 33 & 1.15 & 34 & 32 & 3.49 \\
\hline & Fine Sand & 82 & 15.26 & 104 & 72 & 18.72 \\
\hline & Total Sand & 115 & 14.73 & 136 & 104 & 12.86 \\
\hline & Clay & 614 & 50.09 & 688 & 580 & 8.15 \\
\hline & Silt & 272 & 44.23 & 301 & 206 & 16.29 \\
\hline \multirow[t]{5}{*}{46} & Coarse Sand & 264 & 4.39 & 269 & 259 & 1.66 \\
\hline & Fine Sand & 210 & 2.94 & 214 & 207 & 1.40 \\
\hline & Total Sand & 474 & 1.82 & 476 & 472 & 0.38 \\
\hline & Clay & 417 & 9.10 & 423 & 408 & 2.17 \\
\hline & Silt & 109 & 11.09 & 120 & 99 & 10.22 \\
\hline \multirow[t]{5}{*}{47} & Coarse Sand & 280 & 19.36 & 295 & 252 & 6.90 \\
\hline & Fine Sand & 187 & 13.44 & 206 & 175 & 7.18 \\
\hline & Total Sand & 467 & 6.18 & 471 & 458 & 1.32 \\
\hline & Clay & 434 & 5.90 & 442 & 429 & 1.36 \\
\hline & Silt & 99 & 10.04 & 112 & 88 & 10.12 \\
\hline \multirow[t]{5}{*}{48} & Coarse Sand & 295 & 10.72 & 303 & 279 & 3.64 \\
\hline & Fine Sand & 140 & 1.25 & 141 & 138 & 0.90 \\
\hline & Total Sand & 434 & 10.96 & 444 & 419 & 2.52 \\
\hline & Clay & 460 & 5.35 & 466 & 453 & 1.16 \\
\hline & Silt & 106 & 12.76 & 120 & 94 & 12.06 \\
\hline \multirow[t]{5}{*}{49} & Coarse Sand & 295 & 16.34 & 312 & 273 & 5.54 \\
\hline & Fine Sand & 108 & 9.10 & 120 & 98 & 8.41 \\
\hline & Total Sand & 403 & 7.27 & 410 & 393 & 1.08 \\
\hline & Clay & 452 & 17.46 & 468 & 427 & 3.86 \\
\hline & Silt & 146 & 11.70 & 163 & 139 & 8.04 \\
\hline \multirow[t]{5}{*}{50} & Coarse Sand & 189 & 11.02 & 202 & 177 & 5.84 \\
\hline & Fine Sand & 96 & 6.07 & 102 & 91 & 6.31 \\
\hline & Total Sand & 285 & 16.67 & 303 & 268 & 5.85 \\
\hline & Clay & 476 & 12.70 & 493 & 463 & 2.66 \\
\hline & Silt & 239 & 7.07 & 249 & 234 & 2.95 \\
\hline \multirow[t]{5}{*}{51} & Coarse Sand & 103 & 2.98 & 106 & 99 & 2.90 \\
\hline & Fine Sand & 195 & 4.57 & 201 & 190 & 2.34 \\
\hline & Total Sand & 298 & 7.34 & 307 & 289 & 2.46 \\
\hline & Clay & 548 & 9.27 & 561 & 540 & 1.69 \\
\hline & Silt & 154 & 3.74 & 159 & 150 & 2.42 \\
\hline
\end{tabular}


Table 6. Descriptive statistics of the results from particle-size analyses of 10 Heavy clay soil samples $(\mathrm{n}=4$ replications)

\begin{tabular}{|c|c|c|c|c|c|c|}
\hline Sample & Textural fraction & Mean & Standard deviation & Maximum & Minimum & $\mathbf{C V}$ \\
\hline & & & $-\mathrm{g} \mathrm{k}$ & & & $\%$ \\
\hline \multirow[t]{5}{*}{52} & Coarse Sand & 63 & 7.93 & 74 & 56 & 12.69 \\
\hline & Fine Sand & 87 & 1.82 & 89 & 85 & 2.09 \\
\hline & Total Sand & 150 & 7.04 & 159 & 142 & 4.71 \\
\hline & Clay & 677 & 20.57 & 699 & 658 & 3.03 \\
\hline & Silt & 174 & 24.89 & 197 & 151 & 14.34 \\
\hline \multirow[t]{5}{*}{53} & Coarse Sand & 12 & 4.57 & 18 & 7 & 38.92 \\
\hline & Fine Sand & 8 & 0.95 & 9 & 7 & 12.35 \\
\hline & Total Sand & 20 & 3.87 & 25 & 16 & 19.86 \\
\hline & Clay & 639 & 32.48 & 660 & 591 & 5.07 \\
\hline & Silt & 342 & 28.59 & 384 & 322 & 8.37 \\
\hline \multirow[t]{5}{*}{54} & Coarse Sand & 64 & 6.58 & 72 & 56 & 10.28 \\
\hline & Fine Sand & 90 & 2.87 & 94 & 88 & 3.20 \\
\hline & Total Sand & 154 & 6.94 & 160 & 144 & 4.51 \\
\hline & Clay & 685 & 11.97 & 699 & 670 & 1.74 \\
\hline & Silt & 160 & 8.99 & 173 & 152 & 5.61 \\
\hline \multirow[t]{5}{*}{55} & Coarse Sand & 57 & 5.12 & 62 & 50 & 8.94 \\
\hline & Fine Sand & 86 & 5.25 & 90 & 78 & 6.15 \\
\hline & Total Sand & 143 & 4.57 & 148 & 138 & 3.20 \\
\hline & Clay & 677 & 31.91 & 704 & 634 & 4.71 \\
\hline & Silt & 181 & 29.08 & 218 & 157 & 16.11 \\
\hline \multirow[t]{5}{*}{56} & Coarse Sand & 66 & 5.91 & 71 & 59 & 9.03 \\
\hline & Fine Sand & 116 & 2.06 & 118 & 113 & 1.78 \\
\hline & Total Sand & 181 & 4.85 & 186 & 175 & 2.67 \\
\hline & Clay & 643 & 9.21 & 648 & 629 & 1.43 \\
\hline & Silt & 175 & 7.52 & 185 & 168 & 4.27 \\
\hline \multirow[t]{7}{*}{57} & Coarse Sand & 66 & 5.32 & 71 & 60 & 8.12 \\
\hline & Fine Sand & 120 & 3.55 & 124 & 117 & 2.96 \\
\hline & Total Sand & 186 & 6.02 & 191 & 177 & 3.24 \\
\hline & Clay & 641 & 15.35 & 652 & 618 & 2.39 \\
\hline & Silt & 174 & 11.51 & 191 & 166 & 6.61 \\
\hline & Coarse Sand & 61 & 8.18 & 68 & 52 & 13.52 \\
\hline & Fine Sand & 114 & 8.18 & 122 & 103 & 7.15 \\
\hline \multirow[t]{5}{*}{58} & Total Sand & 175 & 4.34 & 181 & 171 & 2.48 \\
\hline & Clay & 645 & 6.78 & 650 & 635 & 1.05 \\
\hline & Silt & 180 & 10.30 & 194 & 169 & 5.71 \\
\hline & Coarse Sand & 84 & 32.46 & 131 & 58 & 38.87 \\
\hline & Fine Sand & 127 & 4.20 & 131 & 122 & 3.32 \\
\hline \multirow[t]{5}{*}{59} & Total Sand & 210 & 34.91 & 262 & 187 & 16.62 \\
\hline & Clay & 632 & 9.67 & 641 & 618 & 1.53 \\
\hline & Silt & 159 & 37.21 & 188 & 104 & 23.47 \\
\hline & Coarse Sand & 85 & 33.43 & 135 & 63 & 39.21 \\
\hline & Fine Sand & 127 & 6.94 & 135 & 120 & 5.45 \\
\hline \multirow[t]{5}{*}{60} & Total Sand & 213 & 38.33 & 2700 & 193 & 18.04 \\
\hline & Clay & 631 & 9.12 & 642 & 620 & 1.44 \\
\hline & Silt & 157 & 38.10 & 187 & 101 & 24.34 \\
\hline & Coarse Sand & 85 & 32.38 & 133 & 65 & 38.09 \\
\hline & Fine Sand & 131 & 3.51 & 134 & 127 & 2.69 \\
\hline \multirow[t]{3}{*}{61} & Total Sand & 216 & 34.61 & 166 & 192 & 16.06 \\
\hline & Clay & 633 & 14.01 & 642 & 612 & 2.21 \\
\hline & Silt & 152 & 43.19 & 194 & 92 & 28.41 \\
\hline
\end{tabular}


primarily for silt fraction, followed by fine sand, and also for the results for the Heavy Clay soil samples.

The accuracy analysis for nine sandy soil samples showed that the estimations of sand and clay fractions using the RSh were $100 \%$ accurate, once all obtained results were within the confidence intervals defined in table 1 and figure 2. For the silt fraction, the accuracy of the estimations dropped to $55.6 \%$, because the estimated values of four out of nine samples were not within the predefined confidence interval. However, the overall sensitivity or accuracy of the particle-size analysis using the RSh in the dispersion of the sandy soil samples was high, reaching $85.2 \%$. For the medium-textured soil samples, all values obtained using the RSh were within the confidence intervals defined in table 2 , with $100 \%$ accuracy for the three particle size fractions sand, clay and silt (Figure 3). The estimations of the three main textural fractions, sand, clay, and silt were also found to be $100 \%$ accurate for the clayey soil samples (Figure 4) and for the Heavy Clay soil samples (Figure 5). In summary, considering all 61 soil samples of the different textural classes, the mean accuracy of the estimations using the RSh was approximately $96 \%$, a high value.
The dispersion charts for mean values of sand, clay and silt extracted from the reports of Prolab/ IAC (X axis) and those determined using the RSh (Y axis) are illustrated (Figure 6: Sandy and Medium textured soil samples; Figure 7: Clayey and Heavy Clay soil samples). The linear approximations indicate similarities between the two data sources, as evidenced by the proximity of the angular coefficient values $(0.84<\mathrm{m}<1.5)$ to the unit, which characterizes the straight line of perfect correlation. The values of the correlation coefficients were always greater than 0.93 , thus confirming the high correlation between the Prolab/IAC values (reference) and the results obtained with $\mathrm{RSh}$. Of the textural classes, total sand and clay provided the best results, with correlation coefficients greater than 0.98 and differences between the angular coefficients of the straight line and the unit value less than 0.16. Considering all textural classes tested, the largest discrepancies, not only in relation to the correlation coefficient values $(>0.93)$, but also to the deviations of the angular coefficients from unit $(<0.5)$, were observed for the silt fraction estimations. This can be explained by the fact that the silt fraction was determined by difference, leading to cumulative errors in the estimations of this fraction. Ruiz (2005)

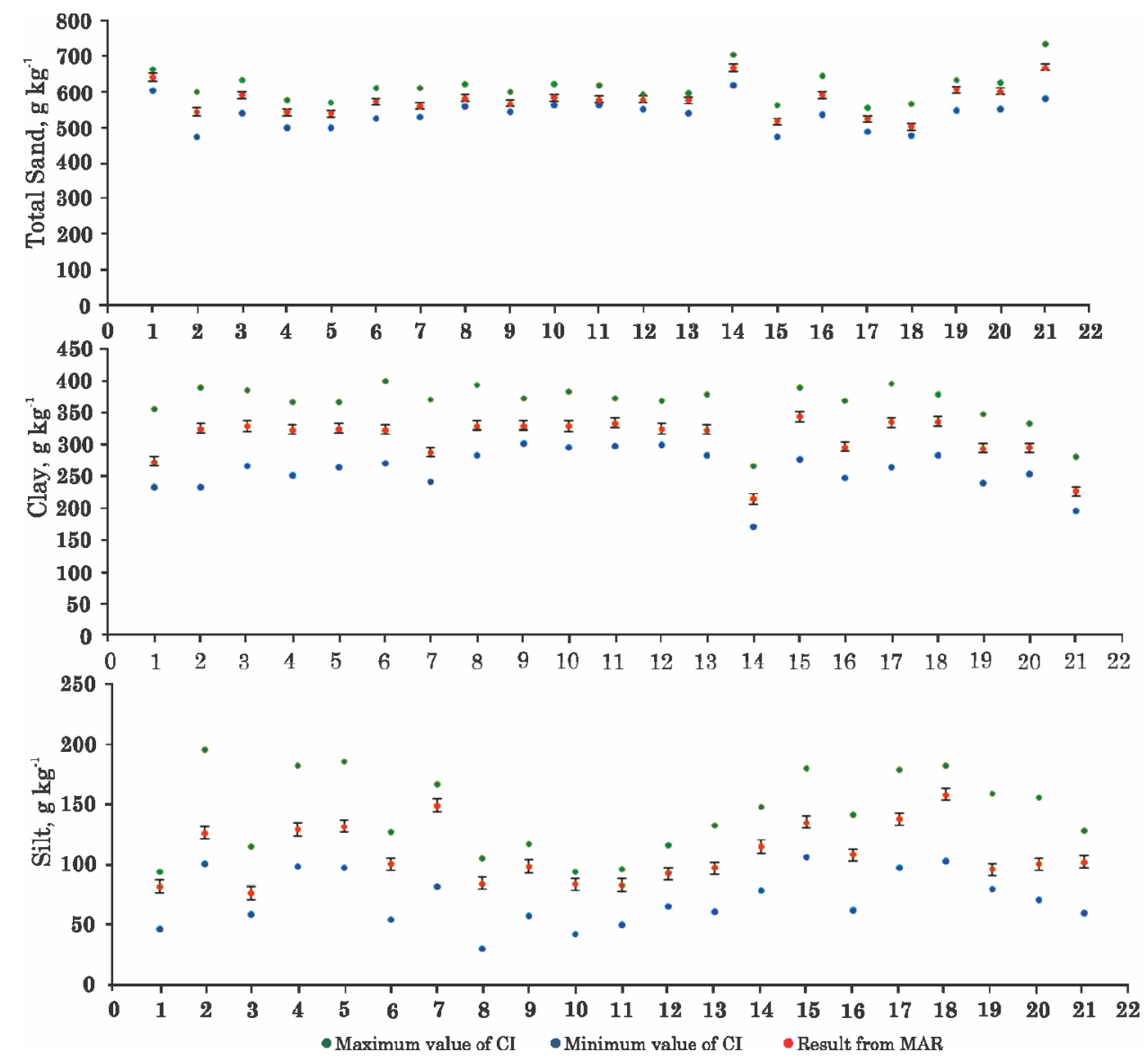

Figure 2. Accuracy analysis of nine sandy soil samples: representation of the minimum and maximum values of the confidence intervals (CI), means and average standard errors (bars) for total sand, silt and clay contents as determined by particle-size analysis using the reciprocal shaker (RSh). 


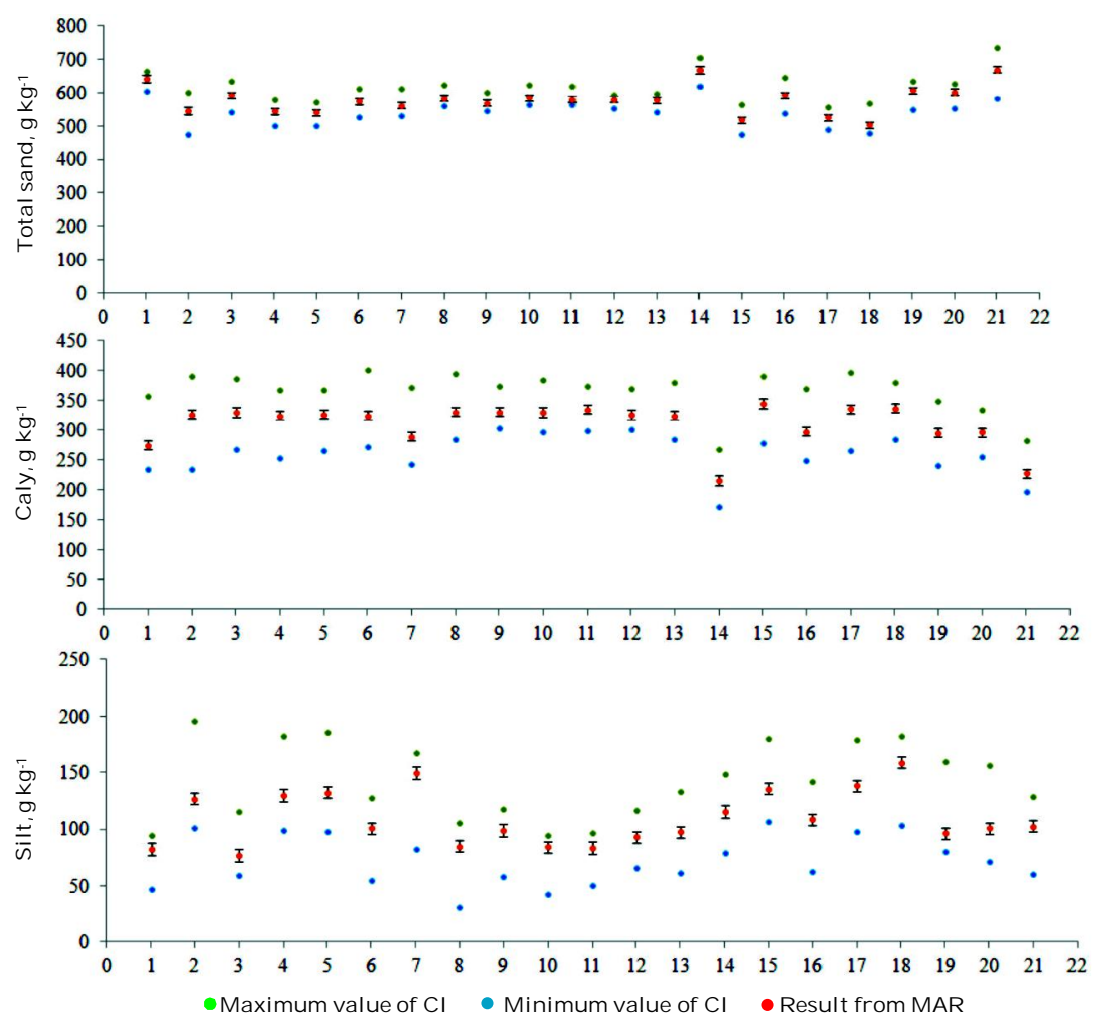

Figure 3. Accuracy analysis of 22 Medium-textured soil samples: representation of the minimum and maximum values of the confidence intervals (CI), means and average standard errors (bars) for total sand, silt and clay contents as determined by particle-size analysis using the reciprocal shaker (RSh).
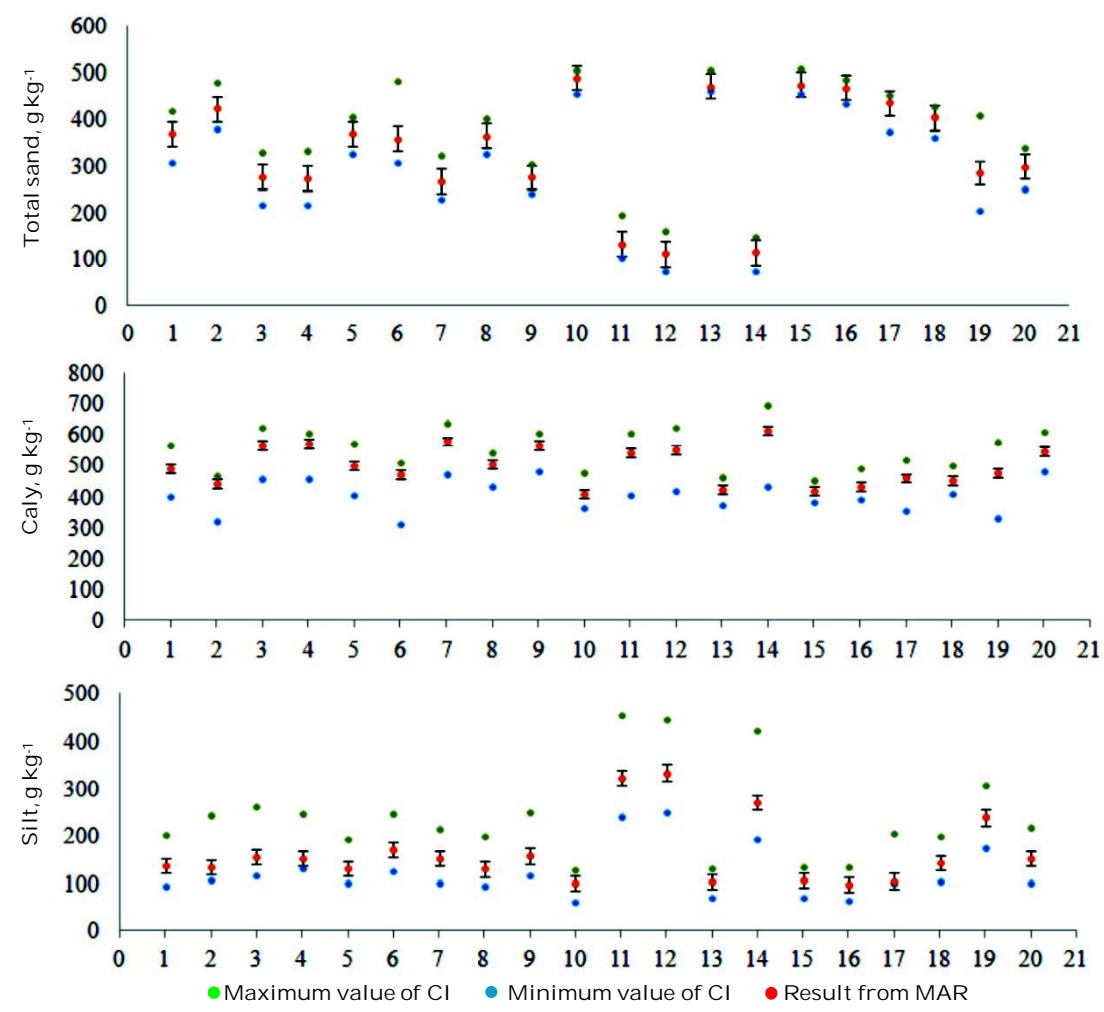

Figure 4. Accuracy analysis for 21 Clayey soil samples: representation of the minimum and maximum values of the confidence intervals (CI), means and average standard errors (bars) for total sand, silt and clay contents as determined by particle-size analysis using the reciprocal shaker (RSh). 

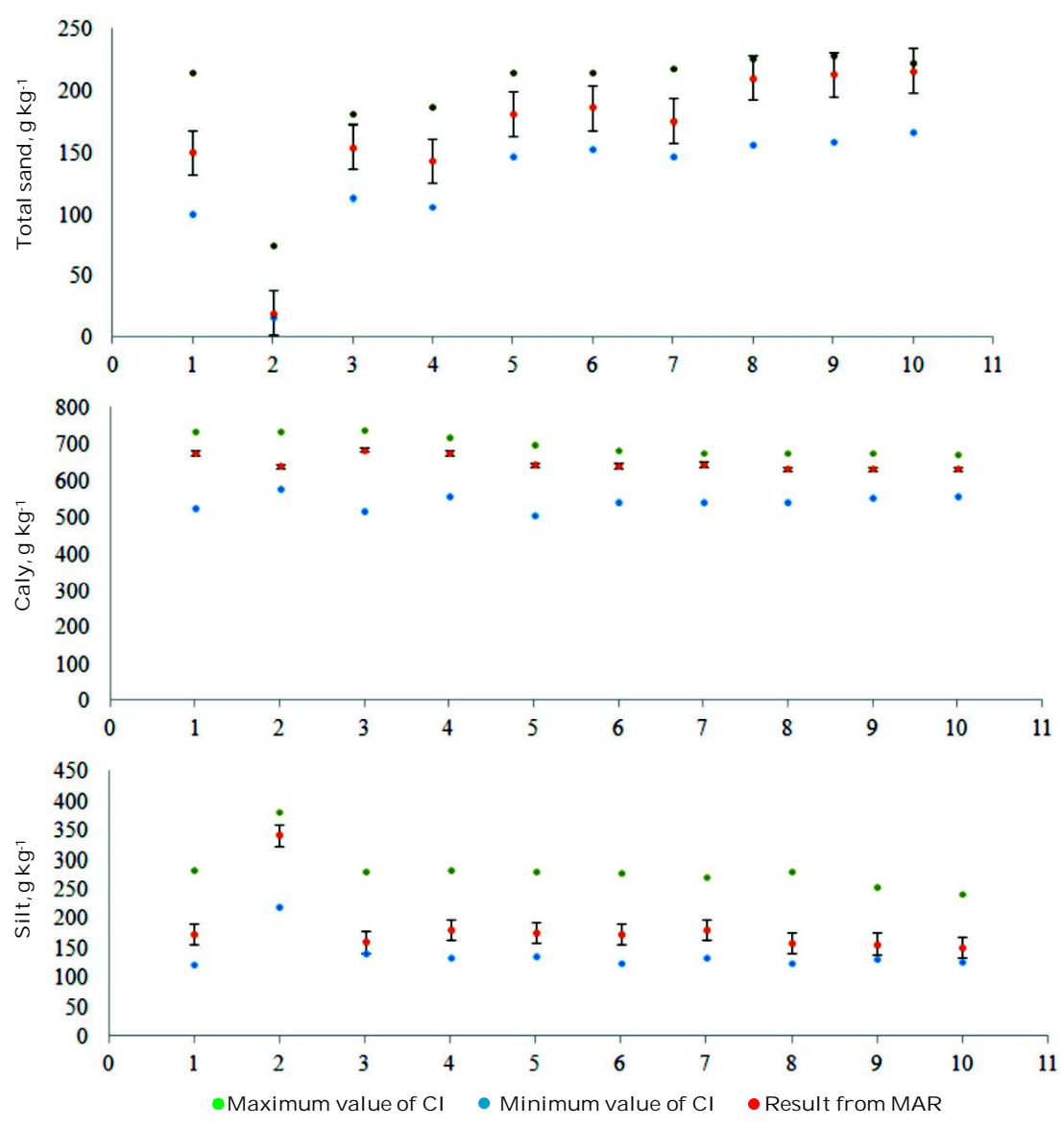

Figure 5. Accuracy analysis for 11 soil samples of the Heavy clay soil textural class: representation of the minimum and maximum values of the confidence intervals (CI), means and average standard errors (bars) for total sand, silt and clay contents as determined by particle-size analysis using the reciprocal shaker (RSh).
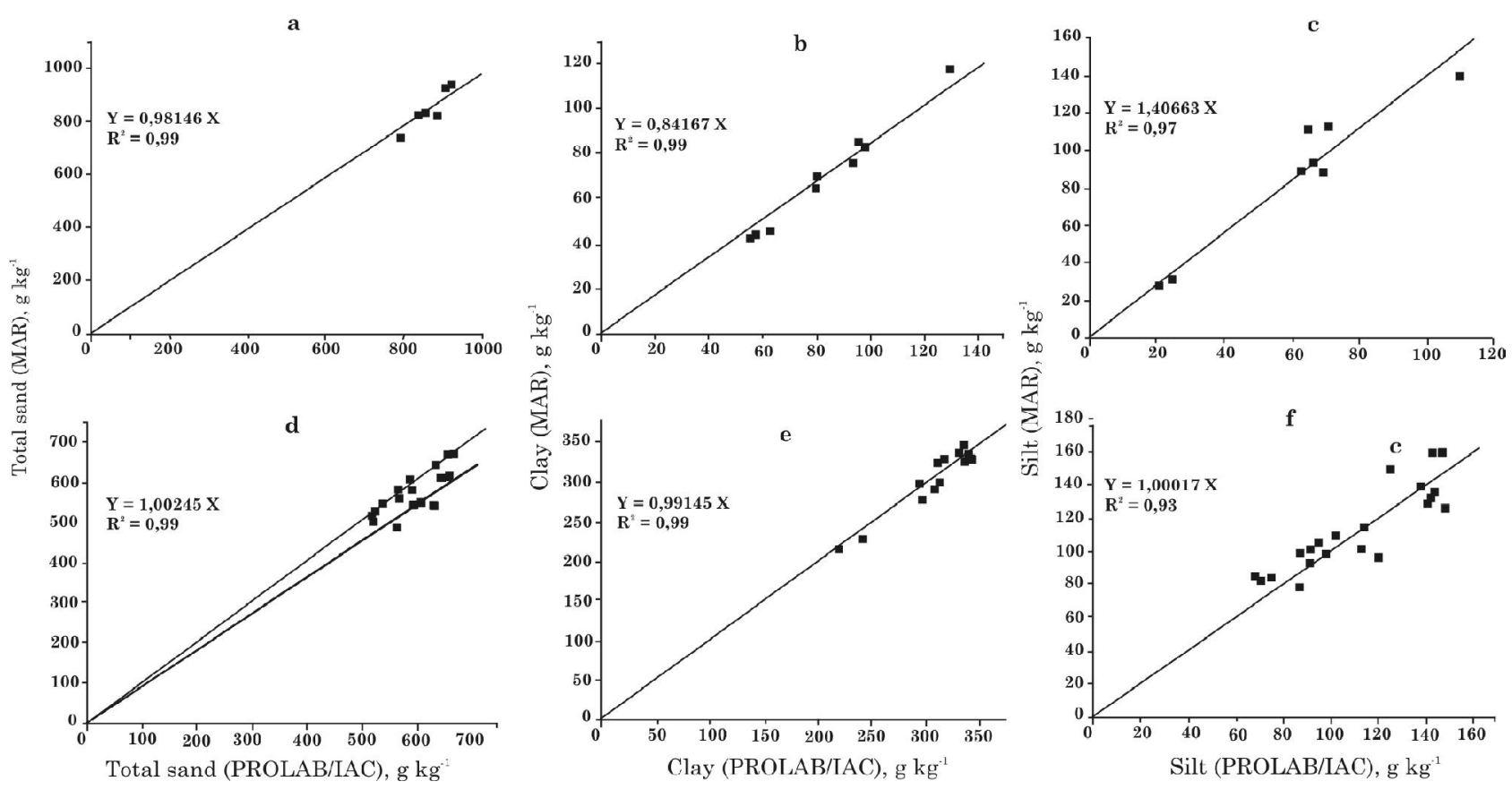

Figure 6. Dispersion charts for mean values of total sand, clay and silt extracted from the data of the Prolab/ IAC and results determined using the RSh for 9 Sandy soil samples $(a, b$ and $c)$ and for 21 Mediumtextured soil samples $(d, e$ and $f)$. 

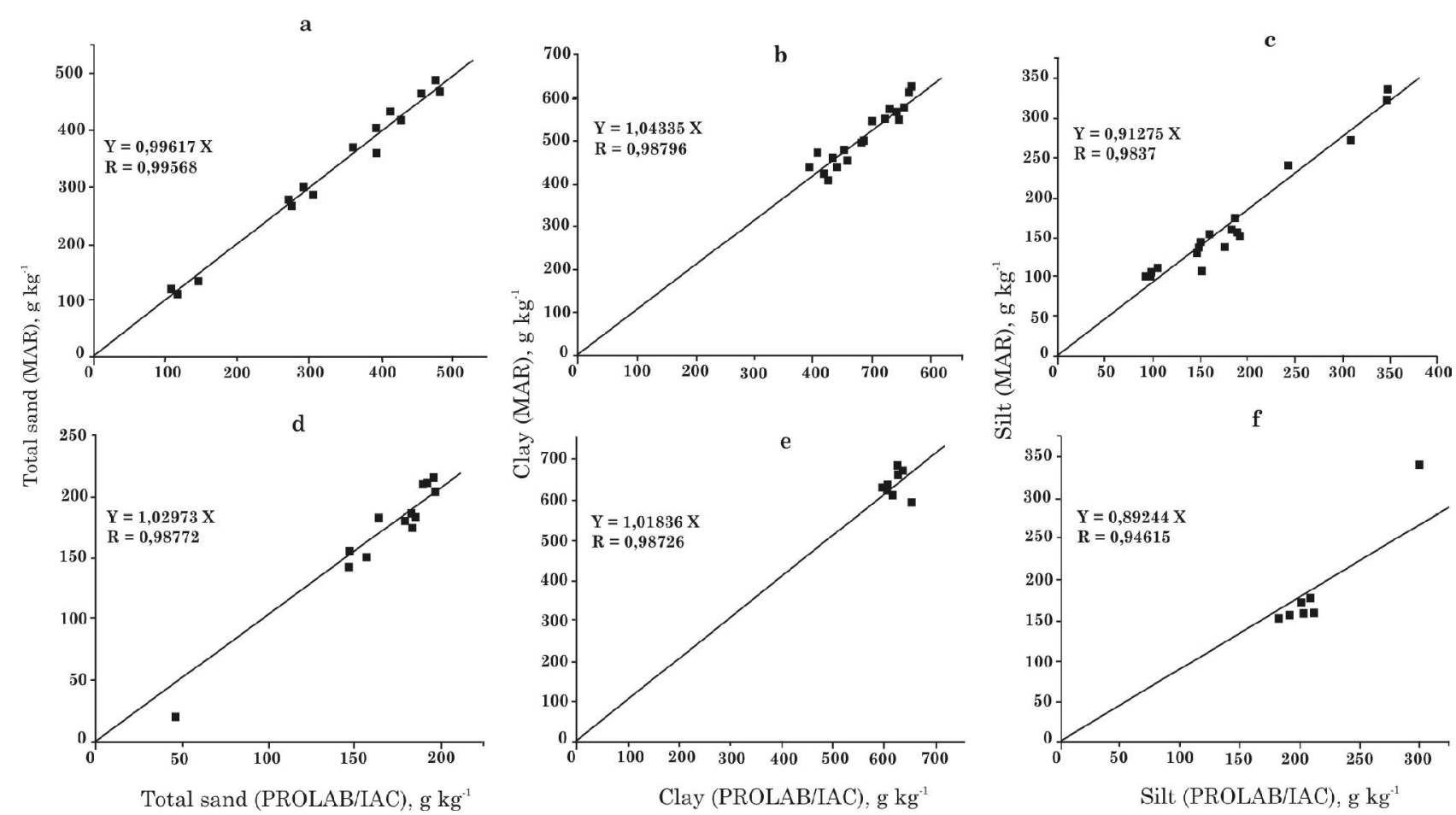

Figure 7. Dispersion charts for mean values of total sand, clay and silt extracted from the data of Prolab/IAC and results determined using the RSh for 20 clayey soil samples $(a, b$ and $c)$ and for 10 heavy clay soil samples ( $d, e$ and $f)$.

demonstrated that the value of the silt fraction calculated by subtracting the other fractions is overestimated. To minimize this problem and possibly increase the accuracy of the determination, the author suggested that an additional volume of the silt and clay suspension should be sampled to estimate silt. However, the effect of this procedure on the accuracy of determinations was not discussed here.

In conclusion, the performance of the reciprocal shaker (RSh) was satisfactory enough to allow its recommendation as a suitable alternative to the conventional devices used for mechanical soil sample dispersion in particle-size analysis. Additional advantages of the equipment are its low cost, the possibility of simultaneous dispersion of up to 40 soil samples, and the option of using ordinary, cheap and easily replaceable glass pots.

\section{CONCLUSIONS}

1. The mechanical dispersion of soil samples from different textural classes, even of the Heavy Clay class by the reciprocal shaker was satisfactory.

2. The tested equipment is a viable alternative for the mechanical dispersion of soil samples for particle-size analysis.

\section{LITERATURE CITED}

BAVER, L.D.; GARDNER, W.H. \& GARDNER, W.R. Soil physics. New York, John Wiley \& Sons, 1972. p.1-53.

CAMARGO, O.A; MONIZ, A.C.; JORGE, J.A. \& VALADARES, J.M.A.S. Métodos de análise química, mineralógica e física de solos do Instituto Agronômico de Campinas. Campinas, Instituto Agronômico de Campinas, 1986. 57p. (Boletim Técnico, 106).

DAY, P.R. Particle fractionation and particle-size analysis. In: BLACK, C.A. ed. Methods of soil analysis. Madison, ASA/ SSSA, 1965. Part 1. p.545-567. (Agronomy Monograph, 9)

EMPRESA BRASILEIRA DE PESQUISA AGROPECUÁRIA EMBRAPA. Sistema Brasileiro de Classificação de Solos. 2.ed. Rio de Janeiro, EMBRAPA SOLOS, 2006. 306p.

EMPRESA BRASILEIRA DE PESQUISA AGROPECUÁRIA EMBRAPA. Manual de métodos de análise de solo. 2.ed. Rio de Janeiro, Centro Nacional de Pesquisa de Solos, 1997. p.27-34.

FLETCHER, G.J.O.; DANILOVICS, P.; FERNANDEZ, G.; PETERSON, D. \& REEDER, G.D. Attributional complexity: An individual diûerences measure. J. Personal. Soc. Psychol., 51:875-884, 1986.

GEE, G.W. \& OR, D. Particle size analysis. In: DANE, J.H. \& TOPP, G.C. Methods of soil analysis. Physical methods. Madison, Soil Science Society of America, 2002. Part 4. p.255-293. 
GROHMANN, F. \& RAIJ, B. van. Dispersão mecânica e prétratamento para análise granulométrica de Latossolos argilosos. R. Bras. Ci. Solo, 1:52-53, 1977.

QUAGGIO, J.A.; CANTARELLA, H. \& RAIJ, B. van. Evolution of the analytical quality of soil testing laboratories integrated in a sample exchange program. Commun. Soil Sci. Plant Anal., 25:1007-1014, 1994.

HILLEL, D. Introduction to soil physics. San Diego, Academic Press, 1982. p.21-39.

NETO, E. L. DE S.; FIGUEIREDO, L. H. A. \& BEUTLER, A. N. Dispersão da fração argila de um Latossolo sob diferentes sistemas de uso e dispersantes. R. Bras. Ci. Solo, 33:723$728,2009$.
RUIZ, H.A. Incremento da exatidão da análise granulométrica do solo por meio da coleta da suspensão (silte + argila). R. Bras. Ci. Solo, 29:297-300, 2005.

SILVA, A.P.; TORMENA, C.A.; FIDALSKI, J. \& IMHOFF, S. Funções de pedotransferência para as curvas de retenção de água e de resistência do solo à penetração. R. Bras. Ci. Solo, 32:1-10, 2008.

TOMASELLA, J.; HODNETT, M.G. \& ROSSATO, L. Pedotransfer functions for the estimation of soil water retention in Brazilian soils. Soil Sci. Soc. Am. J., 64:327-338, 2000.

WARRICK, A.W. \& NIELSEN, D.R. Spatial variability of soil physical properties in the field. In: HILLEL, D., ed. Applications of soil physics. New York, Academia Press, 1980. 385p. 